\title{
Adsorption behavior of activated charcoal and used battery cell carbon as composite for removal of cadmium ion from aqueous solution
}

\section{Priyanka Lahot*}

Department of Chemical Engineering, Deenbandhu Chottu Ram University of Science and Technology, Murthal, Sonipat-131039 (Haryana), India

\section{D.P. Tiwari}

Department of Chemical Engineering, Deenbandhu Chottu Ram University of Science and Technology, Murthal, Sonipat-131039 (Haryana), India

*Corresponding author. E-mail: priyankalahot@gmail.com

\begin{abstract}
To investigate the adsorption behavior of blend activated charcoal and used battery cell carbon for removal of cadmium metal ion, batch adsorption study was used. Batch study for the expansion of parameters such as $\mathrm{pH}$, initial metal ion concentration and adsorbent quantity were utilized. The characterization of the adsorbent samples was done by technique Fourier Infra Red Spectrum (FTIR) and Scanning Electron Microscope (SEM). Adsorption data were computed by Langmuir and Freundlich isotherms. Kinetic data was well explained by Pseudo second order equation, Intra-particle diffusion and Elovich first order equation. Maximum adsorption efficiency was observed to be $75 \%$ at 50:50 ratios of activated charcoal and used battery cell carbon. Purpose of blending activated charcoal and used battery cell carbon reduce the consumption of activated charcoal as it is very costly to use for commercial purposes.
\end{abstract}

Keywords: Activated charcoal, Adsorbent, Adsorption, Blending, Used Battery cell carbon.

\section{INTRODUCTION}

Enacted carbon, likewise called activated charcoal, is a type of carbon prepared to have little, low-volume pores that expands the surface region accessible for adsorption or synthetic responses (Keiluweitet al. 2010;Karnibet al. 2014; Shenet al. 2017). Because of changes in this property, upgrade adsorption productivity of substantial metals found (Winter et al. 2004;Beesleyet al. 2011). Activated charcoal shows high surface area and porous surface as an adsorbent, so blending of two materials give a new form of material known as composite. Composite materials give great surface and improve productivity of adsorbent as already reported by researchers.

Heavy metals as released from industrial sectors electroplating, mining, pharmaceuticals, textile, rubber, nuclear and leather industry (Barakat 2011; Kołodyńska 2013). Main death threat for human health as well as for animals life founds in wastewater released by these sectors at some concentration levels as in form of metal ions of cadmium, arsenic, mercury and lead (Järup 2003). Main source of Cadmium is cigarette smoking and Cadmium effects on health pulmonary effects and kidney damage (Järup 2003;Johri et al., 2010). Past researchers have given number

\section{Article Info}

DOI:10.31018/jans.v10i2.1743

Received: December 12, 2017

Revised: March 24, 2018

Accepted: April 11, 2018

\section{How to Cite}

Lahot, P. and Tiwari, D.P. (2018). Adsorption Behavior of Activated Charcoal and Used Battery Cell Carbon as Composite for Removal of Cadmium ion from aqueous solution. Journal of Applied and Natural Science, 10(2): $608-613$ of ways to remove heavy metals as ion exchange, filtration, coagulation, membrane separation, evaporation and precipitation (Fu and Wang 2011; Sulaymonet al. 2013). Although these techniques gives removal of heavy metals, but at the cost of large land and high maintenance. So far, adsorption has been proven as cheap and easy handling process for the removal of heavy metals - cadmium and lead. For the adsorption technique there is need for adsorbents like that cheap form and biomass derived materials those can play as low cost adsorbents.

The present aim to research was to introduce a composite that may have efficient low cost adsorbent by experimental analysis on Batch scale. Detailed Kinetic and Equilibrium approach improve efficiency of removal and mechanism is well explained by Adsorption isotherms.

\section{MATERIALS AND METHODS}

Preparation of composite: Activated charcoal was selected as base adsorbent and was purchased from local market. Enact material in stifle heater for $2 \mathrm{~h}$ at $250^{\circ} \mathrm{C}$ to remove moisture content and permitted it for cool lastly stuffed in holder. Second of composite utilized battery cell utilized carbon gathers it from waste battery clock 
cell which for the most part toss into dustbin. That waste carbon cell tore up and their carbon dried in stove for fancied hours and gathered in compartment. For composite material mixing of activated charcoal enacted carbon and utilized battery cell carbon being done and utilized for further treatment of aqueous solution made from cadmium sulfate hydrate.

Preparation of material: Cadmium sulfates hydrate unadulterated $\left(3 \mathrm{CdSO} \mathrm{S}_{4} .8 \mathrm{H}_{2} \mathrm{O}\right)$ with proper sum utilized for preparing stock solution with the assistance of refined water. Concentrated hydrochloric acid $(0.1 \mathrm{~N})$ and sodium hydroxide $(0.1 \mathrm{~N})$ arrangement were set up to modify $\mathrm{pH}$ of the treated arrangement. All chemicals were of investigative review and obtained from Merck.

Characterization of adsorbent: FTIR and SEM test testing utilized for both adsorbents independently. FTIR that gives utilization of different functional group information at extreme wavelength that later on defines the reactivity or bonding between the adsorbate and adsorbent molecules. Perkin Elmer RX-FTIR spectrophotometer used to characterize the adsorbent. On the other hand, SEM scanning electron microscope from oxford instruments gives the morphological structure details and surface behavior analysis(GomezSerrano et al. 1996; Siriwardane et al. 2001).

Batch adsorption studies: Impact of parameters like initial metal ion concentration, $\mathrm{pH}$ and adsorbent dosage were studied. All parameters were dissected on cluster scale to test the adsorption of cadmium particle.

Cadmium ion solution of different concentration 10 $-30 \mathrm{mg} / \mathrm{l}, \mathrm{pH}$ variation range $2-12$ and adsorbent dose in the range of $0.05,0.07,0.1,0.15$ and $0.2 \mathrm{~g}$ were considered to observe the effect of these parameters.

Kinetics: Kinetics study provides information about adsorption mechanism and efficiency of adsorbent. A few models to know the behavior of adsorbent with respect to time was employed such as Pseudo first order, Pseudo second order, Elovich and Intra-Particle diffusion model (Patilet al.,(2012).

Equilibrium: To clarify the adsorption phenomenon and to look out for adsorption parameters that clearly verify the mechanism of adsorption during the process, number of adsorption isotherms engaged in terms of equilibrium study like Langmuir and Freundlich.

\section{RESULTS AND DISCUSSION}

\section{Characterization of composite}

FTIR: Fourier Transform Infra Red spectrum con- firms the presence of functional groups on adsorbent surface. FTIR of activated charcoal indicate peaks at $3734 \mathrm{~cm}^{-1}$ and $3008 \mathrm{~cm}^{-1}$ that means $\mathrm{sp}^{2}$ hybridization exist. Peak at $918 \mathrm{~cm}^{-1} \mathrm{OH}$ bend and $1517 \mathrm{~cm}^{-1}$ shows presence of C-C ring asymmetric or symmetric stretching vibrations that responsible for adsorption. Likewise composite also gives presence of nitro groups. Cadmium loaded composite shows presence of free $\mathrm{OH}$ group at $3688 \mathrm{~cm}^{-1}$ and $1216 \mathrm{~cm}^{-1}$ indicate $\mathrm{CH}$ bend and vibrations and $924 \mathrm{~cm}^{-1}$ that means $\mathrm{OH}$ bend vibrations clearly responsible for adsorption process.

SEM: Scanning electron microscopy provides information about morphological structure. Morphological image depicts the existence of cavities on the surface of adsorbent which means that it allow more cations to occupy the sites. Fig. 2i.e of used battery cell carbon, activated carbon that clearly gives indication of cavities adsorbent surfaces. Both adsorbent samples were analyzed under proper observations and tested in the size range of $10 \mu \mathrm{m}$ and $50 \mu \mathrm{m}$. similar kind as cited in (Edokpayi et al., 2015).

Effect of composition: For Optimum ratio of activated charcoal to used carbon composite for removal of cadmium ion, different mass fractions were chosen as 100:0, 30:70, 50:50 and 60:40.It was found that high adsorption efficiency of $75 \%$ obtained for 50:50 ratio in comparison to other ratios selected.

Effect of initial metal ion concentration, $\mathrm{pH}$ and adsorbent dose: Effect of initial metal ion concentration is one of parameter which decides the optimum concentration level. Upon varying the concentration removal efficiency increases up to $20 \mathrm{mg} / \mathrm{l}$ and then it started decreasing when initial concentration was increased beyond of initial concentration of $\mathrm{Cd}$. It is explained as initially lots of active sites were available to hold up cations resulting in increased removal efficiency till equilibrium attained afterwards removal efficiency starts decreasing as varying concentration due to overlapping on the active sites. Similar kind of behavior reported in literature (Gaya et al., 2015).

On $\mathrm{pH}$ influence, ionization as well as surface charge of adsorbent indication as presented in Fig. 4, introductory $\mathrm{pH}$ in acidic medium no expulsion of cadmium because of high accessibility of positive particles however between 5-8 maximum numbers of cadmium acquired as ascertained by removal efficiency as cited elsewhere(Naiya et al., 2009; Abadeh and Irannajad, 2017).

In order to determine the influence of adsorbent

Table 1. Factors evaluated from different kinetic models.

\begin{tabular}{llllllllll}
\hline \multicolumn{2}{l}{ Pseudo second order } & \multicolumn{3}{l}{ Natranjan and khalaf } & Weber-morris & \multicolumn{3}{l}{ Elovich } \\
\hline $\mathrm{q}_{\mathrm{e}}(\mathrm{mg} / \mathrm{g})$ & $\mathrm{K}_{2}(\mathrm{mg} / \mathrm{g} / \mathrm{min})$ & $\mathrm{h}$ & $\mathrm{K}$ & $\mathrm{R}^{2}$ & $\mathrm{~K}(\mathrm{mg} / \mathrm{g} / \mathrm{min})$ & $\mathrm{R}^{2}$ & $\alpha$ & $\beta$ & $\mathrm{R}^{2}$ \\
\hline 1.25 & 0.029 & 0.046 & 0.004 & 0.817 & 0.071 & 0.893 & 0.049 & 3.921 & 0.929
\end{tabular}

$\mathrm{q}_{\mathrm{e}}$ amount of metal ion adsorbed, $\mathrm{K}_{2}$ second order rate constant, $\mathrm{h}$ initial adsorption rate, aElovich model constant, $\beta$ desorption constant 
Table 2. Factors calculated from adsorption isotherms.

\begin{tabular}{llll}
\hline Langmuir & \multicolumn{3}{c}{ Freundlich } \\
\hline $\mathrm{q}_{\mathrm{m}}$ & $\mathrm{R}^{2}$ & $\mathrm{~K}_{\mathrm{f}}$ & $\mathrm{n}$ \\
10.00 & 0.985 & 1.885 & 0.680 \\
\hline
\end{tabular}

$\mathrm{q}_{\mathrm{m}}$ monolayer (maximum) adsorption capacity $\mathrm{mg} / \mathrm{g}$, $\mathrm{K}_{\mathrm{f}}$ constant factor affecting adsorption capacity, $\mathrm{n}$ intensity of adsorption

amount, adsorbent dosage was increased from 0.05 to $0.1 \mathrm{~g}$ and it was found that adsorption capacity as well as removal efficiency increased up to a specified range $0.1 \mathrm{~g}$ though beyond this it starts to decrease as adsorbent dose increased for $0.15 \mathrm{~g}$ and $0.2 \mathrm{~g}$. it is because of the reason that more sites converted in the form of multilayer since initially metal ions already has been up taken by active sites and no more metal ions were available to adsorb on adsorbent surface.

Kinetic study: Time variation examination describes the functionality of adsorption process. A couple of models have been proposed by numerous past scientists distinct sign of mass exchange diffusion, film dispersion, starting rate of adsorption, desorption steady esteems and some rate consistent esteems. Models such as Pseudo first order, Pseudo second order, Elovich, WeberMorris and Natranjan and Khalaf first order equation were used.

Pseudo Second order kinetics equation is $\mathrm{t} / \mathrm{q}_{\mathrm{t}}=1 /\left(\mathrm{K}_{2} \mathrm{q}_{\mathrm{e}}^{2}\right)+\mathrm{t} / \mathrm{q}_{\mathrm{e}}$ $\mathrm{K}_{2}=$ second order rate constant ( $\mathrm{mg} / \mathrm{g} / \mathrm{min}$ ).

Pseudo second order indicates plot sign of linearity between $\mathrm{t} / \mathrm{q}_{\mathrm{t}}$ and contact time. Fig 6 signs quite linear following behavior decides the order of $2^{\text {nd }}$ and also chemisorptions following nature for the adsorption process. All tests were performed at room temperature of $35^{\circ} \mathrm{C}$ with specified contact time and constant stirring using magnetic stirrer plate. Constant calculated by using slope and intercept mentioned in table1.

Intra particle diffusion equation was used by cited literature(Qiu et al., 2009)

$\mathrm{q}_{\mathrm{t}}=\mathrm{Kt} \mathrm{t}^{0.5}$

where $\mathrm{K}$ is diffusion rate constant $(\mathrm{mg} / \mathrm{g} / \mathrm{min})$. Intra particle diffusion model also known as Weber
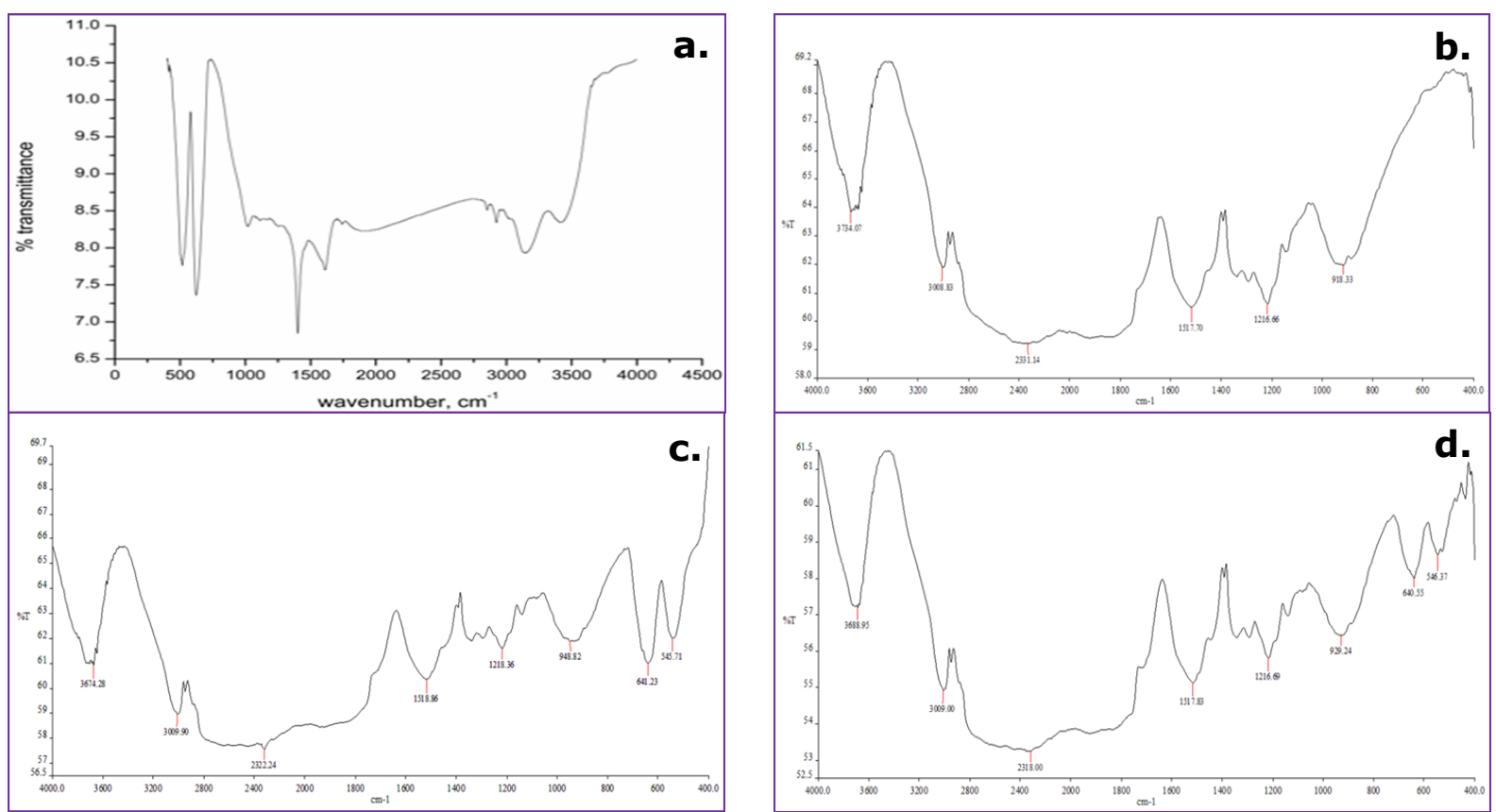

Fig. 1. FTIR spectrum of A) battery cell carbon B) activated charcoal C) composite D) Cd loaded composite.
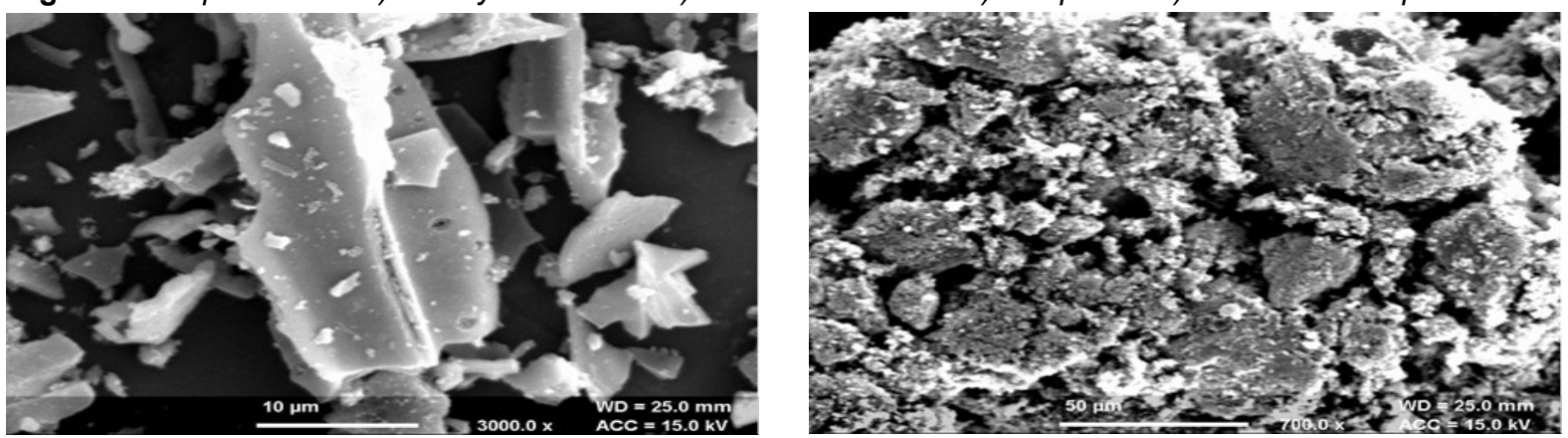

Fig. 2. SEM images of battery cell carbon and activated charcoal. 


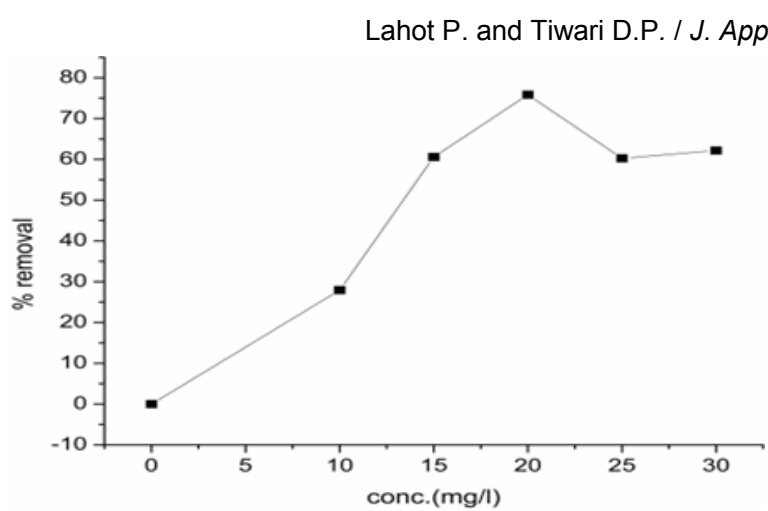

Fig. 3. Effect of initial metal ion concentration on cadmium metal ion adsorption.

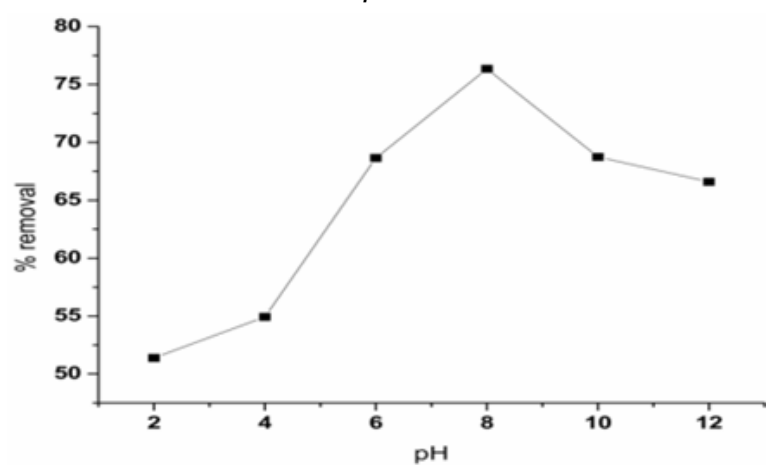

Fig. 4. Effect of $\mathrm{pH}$ on cadmium metal ion adsorption.

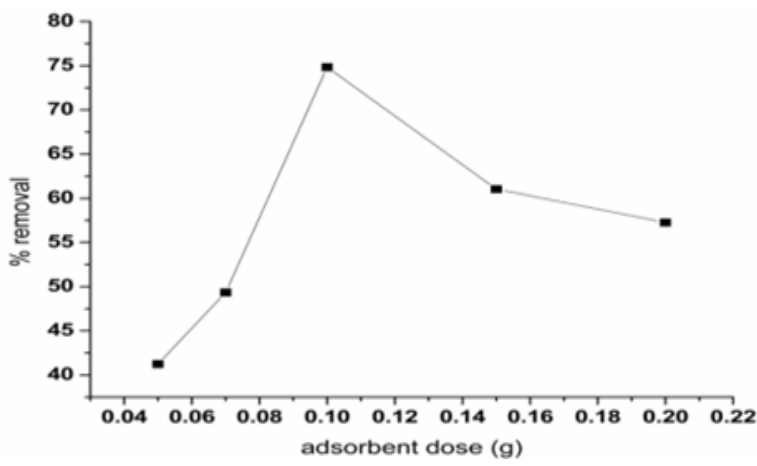

Fig. 5. Effect of adsorbent dose on cadmium metal ion adsorption.

-Morris model comes under mass transfer diffusion model. This model demonstrates the idea of mass exchange. Mass exchange depends on two principle focuses whether process following film dispersion or experiencing limit layer impact. In Fig. 7, Plot amongst $q_{t}$ and $t^{0.5}$ gives high estimation of correlation coefficient that a sign of well fit. Likewise the way that focuses said on plot don't cross the beginning means no boundary layer impact exists. If curve coincides with origin which means that there is only rate determining step exist but if in case it don't coincides with origin that conclude that several steps play in the role of diffusion.

Natranjan and Khalaf first order equation is (Patil et al., 2012)

$\log \left(\mathrm{C}_{\mathrm{o}} / \mathrm{C}_{\mathrm{t}}\right)=(\mathrm{K} / 2.303) \mathrm{t}$

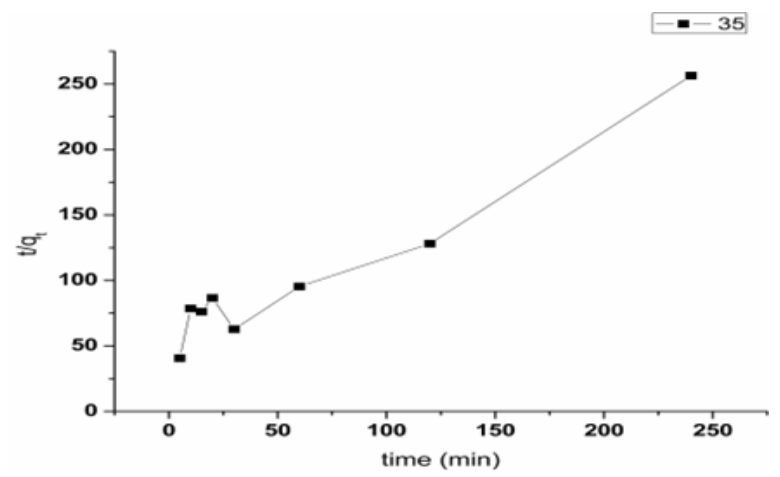

Fig. 6. Pseudo second order plot of cadmium metal ion adsorption.

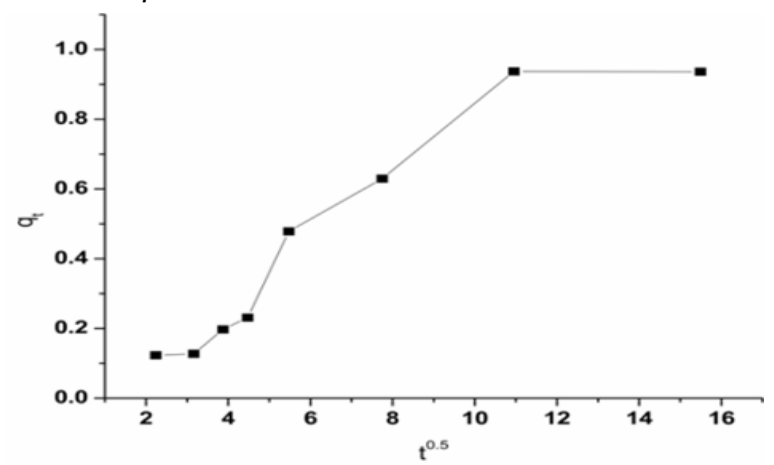

Fig. 7. Intra particle diffusion plot of cadmium metal ion adsorption.

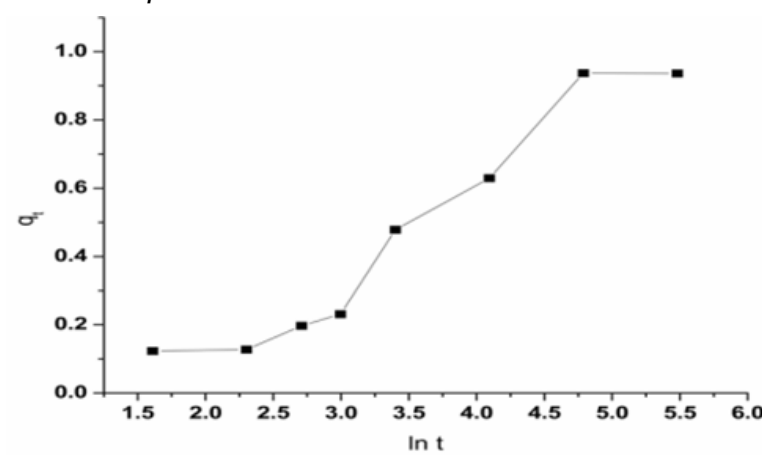

Fig. 8. Elovich first order plot of cadmium metal ion adsorption.

Where $\mathrm{K}$ is first order rate constant and calculated by slope of plot. Relationship coefficient esteem was not high that indicated not all around fitted and don't take part in adsorption process.

Elovich linear form equation is

$q_{t}=1 / \beta[\ln (\alpha \beta)]+\ln t / \beta$

Two constants $\alpha$ and $\beta$, initial rate of adsorption and desorption constant calculated from slope and intercept values by plotting between $\ln t$ and $q_{t}$. this model Fig 8 introduced linear relation as shown by correlation coefficient $R^{2}$. This model in view of suspicion that strong surface is heterogeneous. Constant parameters value shown in Table 1.

Equilibrium study: Adsorption isotherms that describe the mechanism of process and capacity of adsorbent for metal ion. Familiar isotherms are 


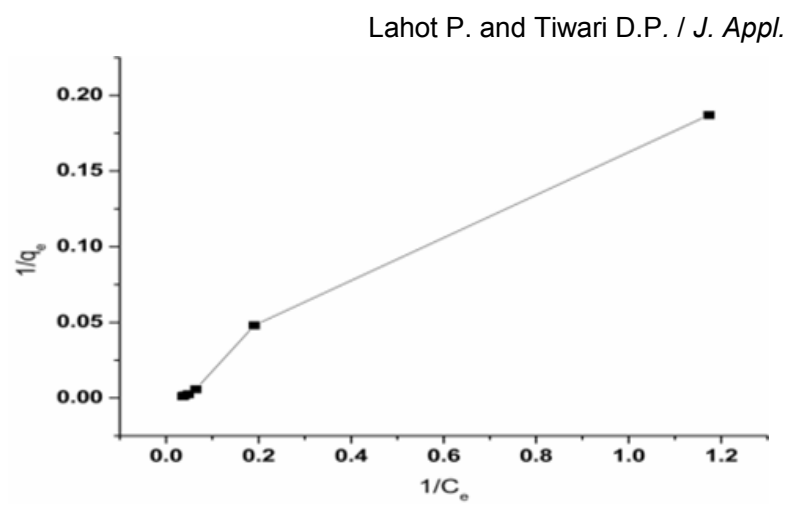

Fig. 9. Langmuir adsorption isotherm plot of cadmium metal ion.

Langmuir and Freundlich models (Attia et al., 2010).

Langmuir $1 / \mathrm{q}_{\mathrm{e}}=\left(1 / \mathrm{q}_{\mathrm{m}}{ }^{*} \mathrm{~K}\right)\left(1 / \mathrm{C}_{\mathrm{e}}\right)+1 / \mathrm{q}_{\mathrm{m}}$

(5)

Freundlich $\log \mathrm{q}_{\mathrm{e}}=\log \mathrm{K}+1 / \mathrm{n}{ }^{*} \log \mathrm{C}_{\mathrm{e}}$ (6)

$\mathrm{q}_{\mathrm{m}}$ is monolayer adsorption limit $(\mathrm{mg} / \mathrm{g})$

Langmuir isotherm assumes no adsorbateadsorbate interaction; monolayer adsorption on surface and all molecules behaves ideally. In Fig 9, Langmuir models depended on suspicion that maximum adsorption corresponds to an immersed mono layer of solute atoms on surface of adsorbent. Similar work has been cited in literature (Hallet al., 1966;Dadaet al., 2012).

As many past researchers reported, $q_{m}(\mathrm{mg} / \mathrm{g})$ values with different adsorbents such as Patil et al., (2012) reported Almond tree bark powder $(7.57 \mathrm{mg} / \mathrm{g})$, Teak tree bark powder $(10.10 \mathrm{mg} / \mathrm{g})$. Mousavi et al., (2009) presented $22.35 \mathrm{mg} / \mathrm{g}$ with adsorbent Waste tire rubber ash. Bulut and Zeki (2007) reported $5.76 \mathrm{mg} / \mathrm{g}$ with Sawdust and Khanet al., (2012) presented $3.24 \mathrm{mg} / \mathrm{g}$ with Oil cake, while present study found $10 \mathrm{mg} / \mathrm{g}$ with adsorbent Activated charcoal and used battery cell carbon as composite.

Freundlich adsorption isotherm speaks to the connection between measures of metal adsorbed per unit mass of adsorbent and grouping of metal particle in the arrangement. Fig10 gives the straight line with respect to correlation coefficient. On assessment of factor substantial is estimation of $\mathrm{K}$ expansive will be limit of adsorbent. Where $n$ speaks to the biosorption deviation from linearity. On the off chance that $n=1$ speak to straight, $n>1$ physiosorption process, $\mathrm{n}<1$ chemisorptions process shape.Same results reported elsewhere (Annadurai et al., 2003).

All constant parameters presented in Table 2.

Thermodynamic study: To confirm the feasibility and spontaneity of the process by calculating Gibbs free energy change $(\Delta G)$, enthalpy change $(\Delta \mathrm{H})$ and entropy change $(\Delta S)$ with help of following equation(BulutandZeki,2007)

$\Delta \mathrm{G}=\Delta \mathrm{H}-\mathrm{T} \Delta \mathrm{S}$

$\operatorname{lnK} K_{0}=-\Delta G / R T$

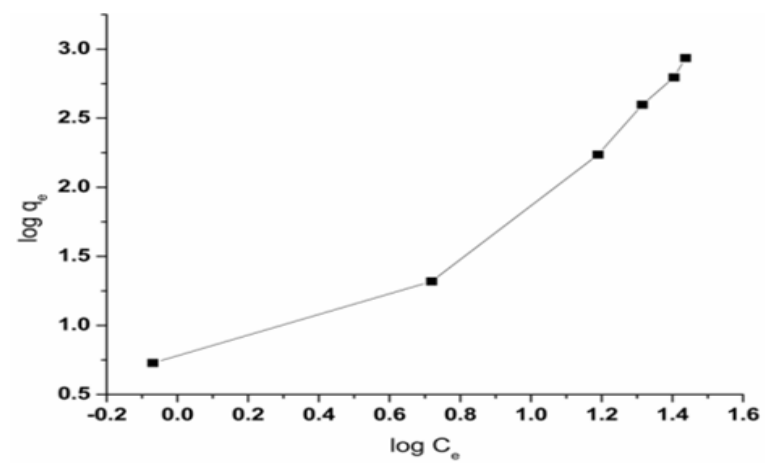

Fig. 10. Freundlich adsorption isotherm plot of cadmium metal ion.

$\ln \mathrm{K}_{\mathrm{o}}=\Delta \mathrm{S} / \mathrm{R}-\Delta \mathrm{H} / \mathrm{RT}$

where $\mathrm{K}_{\mathrm{o}}$ equilibrium constant. $\Delta \mathrm{H}$ and $\Delta S$ calculated by intercept and slope by plotting between In $\mathrm{K}_{\mathrm{o}}$ and $1 / \mathrm{T}$. Negative value of $\Delta \mathrm{G}$ clearly indicates the spontaneous process, favorable and endothermic process.

\section{Conclusion}

Influence of parameters initial metal ion concentration, $\mathrm{pH}$ and adsorbent dose quite affected by adsorption behavior of cadmium metal on the activated charcoal - used battery cell carbon composite. Kinetics models showed good response in adsorption of metal ion and followed by second order behavior as well Elovich and Intra-particle diffusion also gave well response with correlation coefficient. Adsorption isotherms well explained by Langmuir and Freundlich isotherms. From the effective adsorbent point of view physical mixing of activated charcoal and used battery cell carbon also can give good adsorption capacity and fast reaction process.

\section{REFERENCES}

Abadeh, Z. A. and Irannajad M. (2017). Removal of $\mathrm{Ni}$ and $\mathrm{Cd}$ ions from aqueous solution using iron dustzeolite composite: Analysis by thermodynamic, kinetic and isotherm studies.Chemical Research in Chinese Universities, 33(2): 318-326.

Annadurai, G., Juang, RS. and Lee, DJ. (2003). Adsorption of heavy metals from water using banana and orange peels.Water Sci \& Techno, 47(1): 185-190.

Attia, A., Khedr, SA and Elkholy, SA. (2010). Adsorption of chromium ion (VI) by acid activated carbon. Brazil $J$ Chem Eng, 27(1): 183-193.

Barakat, M. (2011). New trends in removing heavy metals from industrial wastewater. ArabianJ Chemis, 4 (4): 361-377.

Beesley, L., Moreno-Jimenez E., Jose L., Harris E., Robinson B. and Sizmur T. (2011). A review of biochars' potential role in the remediation, revegetation

and restoration of contaminated soils. Environ Pollu, 159 (12): 3269-3282.

Bulut, Y. and T. Zeki (2007). Removal of heavy metals from aqueous solution by sawdust

adsorption.J Environ Sci, 19(2): 160-166.

Dada, A., Olalekan AP., Olatunya, AM. and Dada, O. (2012). Langmuir, Freundlich, Temkin and Dubinin- 
Radushkevich isotherms studies of equilibrium sorption of $\mathrm{Zn} 2+$ unto phosphoric acid modified rice husk.IOSR J App Chemis, 3(1): 38-45.

EdokpayiN. Joshua, Odiyo J.O. Msagati T.A.M. and Popoola O. (2015). A Novel Approach for the Removal of Lead(II) lon from Wastewater Using Mucilaginous Leaves of Diceriocaryum eriocarpum Plant, (Ii). sustainability. 14026-14041.

Fu, F. and Q. Wang (2011). Removal of heavy metal ions from wastewaters: a review. J Environ Mgmt, 92 (3): 407-418.

Gaya, UI., Otene, E. and Abdullah, AH. (2015). Adsorption of aqueous $\mathrm{Cd}(\mathrm{II})$ and $\mathrm{Pb}$ (II) on activated carbon nanopores prepared by chemical activation of doum palm shell.SpringerPlus, 4(1): 458.

Gomez-Serrano, V., Pastor-Villegas, A., Perez-Florindo, C., Duranvalle, C., Valenzula-Calahorro. (1996). FTIR study of rockrose and of char and activated carbon.J Analytical \& Applied pyrolysis, 36(1): 71-80.

Hall, K. R., Eagleton,LC. Acrivos, A. and Vermeulen, T. (1966). Pore-and solid-diffusion kinetics in fixed-bed adsorption under constant-pattern conditions.Industrial \& Eng Chemis Fundamentals, 5(2): 212-223.

Järup, L. (2003). Hazards of heavy metal contamination. British Medical Bulletin, 68(1): 167-182.

Johri, N., Jacquillet, G. and Unwin, R. (2010). Heavy metal poisoning: the effects of cadmium on the kidney. Biometals, 23(5): 783-792.

Karnib, M., Kabbani A., Holail H and Olama Z. . (2014). Heavy Metals Removal Using Activated Carbon Silica and Silica Activated Carbon Composite.Energy Procedia, 50: 113-120.

Keiluweit, M., Peter S. Nico, Mark G. Johnson and Markus Kleber. (2010). Dynamic molecular structure of plant biomass-derived black carbon (biochar).Environ Sci \& Techno, 44(4): 1247-1253.

Khan Ali M., Ngabura M., Choong TS., Masood HO. and Chuah LA. (2012). Biosorption and desorption of nickel on oil cake: Batch and column studies. Bioresource Techn., 103: 35-42.

Kołodyńska, D. (2013). Application of a new generation of complexing agents in removal of heavy metal ions from different wastes.Environ Sci \&Poll Res., 20(9): 5939-5949.

Mousavi, HZ., Jahed, A. H. and Dehghani SAM. (2009). Removal of lead from aqueous solution using waste tire rubber ash as an adsorbent. Brazilian Journal of Chemical Engineering, 27(1): 79-87.

Naiya, TK., Bhattacharya AK.and Das SK. (2009). Adsorption of $\mathrm{Cd}$ (II) and $\mathrm{Pb}$ (II) from aqueous solutions on activated alumina. J Colloid \& Interface Sci., 333 (1): 14-26.

Patil, S., Renukdas S and Patel N. (2012). Kinetic and Thermodynamic study of removal of $\mathrm{Ni}$ (II) ions fromaqueous solutions using low cost adsorbents. Int. J. Environ. Sci., 3(1): 322-340.

Qiu, H., Lu LV, Bing-cai PAN, Qing-jian ZHANG, Weiming ZHANG and Quan-xing ZHANG(2009). Critical review in adsorption kinetic models.J ZhejiangUniversity-Science A., 10(5): 716-724.

Shen, Z., Zhang Y., Mcmillan O., Jin F. and Abir AlTabbaa (2017). Characteristics and mechanisms of nickel adsorption on biochars produced from wheat straw pellets and rice husk. Environ Sci and Poll Res.24(14): 12809-12819.

Siriwardane, R. V., Ming-Shing Shen, Edward P Fischen and James A. Poston (2001). Adsorption of $\mathrm{CO}_{2}$ on molecular sieves and activated carbon.Energy \& Fuels, 15(2): 279-284.

Sulaymon, A.H., Mohammed A.A. and AL-Musawi T.J. (2013). Competitive biosorption of lead, cadmium, copper, and arsenic ions using algae. Environ Sci \& Poll Res, 20(5): 3011-3023.

Winter, M. and R. J. Brodd (2004). What are batteries, fuel cells, and supercapacitors?, ACS Publications. 